\title{
Risk factors for epilepsy after ischemic stroke in children
}

\section{Çocuklarda iskemik inme sonrası epilepsi için risk faktörleri}

\author{
Faruk İNCECIK, Özlem M. HERGÜNER, Şeyda BESEN
}

Çukurova Üniversitesi Tip Fakültesi, Adana

\begin{abstract}
Objective: We performed this study to determine the incidence of seizures and poststroke epilepsy and risk factors of post-stroke epilepsy after childhood ischemic stroke. Methods: In this study, we retrospectively analyzed data from children who had ischemic stroke.

Results: Of the one hundred and two children, mean age of stroke onset was $67.32 \pm$ 25.48 months (1-180 months). There were $56(54.9 \%)$ boys and $46(45.1 \%)$ girls in the study . Of the 102 patients, $39(38.2 \%)$ had seizures. Twenty seven $(69.2 \%)$ had earlyonset post-stroke seizures, and $12(30.8 \%)$ had late-onset post-stroke seizures. Epilepsy were detected in $17(16.7 \%)$ of the patients. Eight of them had early-onset and nine had late-onset post-stroke seizures. We found that cortical involvement and late onset post-stroke seizure are predictors of the development of post-stroke epilepsy.

Conclusions: Post-stroke seizures and epilepsy in children are common. Therefore, further studies are needed to describe risk factors for the development of post-stroke epilepsy in this population.
\end{abstract}

Keywords: Ischemic stroke, post-stroke epilepsy, risk factors, children

\section{$\ddot{\mathbf{o z}}$}

Amaç: Bu çalışma, çocukluk çağı iskemik inme sonrasında nöbet, epilepsi ve epilepsi insidansı ile risk faktörlerinin saptanması için yapıldı.

Yöntem: Çalışmada, iskemik inme geçiren çocukların verileri retrospektif olarak analiz edildi.

Bulgular: İskemik inme geçiren 102 hastanın yaş ortalaması 67,32 $\pm 25,48$ ay (1-180 ay) idi. Elli altısı $(\% 54,9)$ erkek ve 46 'sı ise $(\% 45,1)$ kız idi. Yüz iki hastanın, 39'u $(\% 38,2)$ nöbet geçirmişti. Yirmi yedi $(\% 69,2)$ hastanın nöbeti erken başlangıçlı iken, $12(\% 30,8)$ hastanın nöbeti geç başlangıçlıydı. Hastaların 17 'sinde $(\% 16,7)$ epilepsi gelişmişti. Bunların 8'i erken başlangıçlı nöbeti olan hastayken, 9'u ise geç başlangıçlı nöbeti olan hastalardı. Lezyonun lokalizasyonu ve nöbet başlama zamanı epilepsi için risk faktörü saptandı.

Sonuç: İnme sonrası nöbetler ve epilepsi çocuklarda sık görülür. Bu nedenle, bu populasyonda, inme sonrası epilepsi gelişme riskini saptamak için daha fazla çalışmaya gereksinim vardır.

Anahtar kelimeler: İskemik inme, epilepsi, risk faktörleri, çocuklar

Alındığı tarih: 18.01.2017

Kabul tarihi: 05.10.2017

Yazışma adresi: Uzm. Dr. Faruk İncecik, Çukurova Üniversitesi Çocuk Bölümü, Adana Türkiye

e-mail: fincecik@yahoo.com

\section{INTRODUCTION}

Childhood stroke is defined as a sudden onset of neurological deficit due to a cerebrovascular disorder, which lasts for 24 hours or longer. The incidence of pediatric stroke has been estimated as 2 to 13 per 100,000 children ${ }^{(1,2)}$. Strokes are currently broadly classified as either hemorrhagic or ischemic. Ischemic stroke is more common.
Stroke is presented with various neurological complications at onset including focal signs (hemiparesis, visual field deficit, and speech deficit), diffuse signs (decreased level of consciousness, headache), and seizures ${ }^{(3)}$. Seizures and epilepsy are complications which can occur after ischemic stroke. The incidence of post-stroke seizures in children is known to be high ${ }^{(4,5)}$.

There have been reports about the incidence of 
seizures after stroke in adults ${ }^{(6)}$, but there are few studies concerning seizures and epilepsy occurring after ischemic stroke in children ${ }^{(5,7-9)}$. Therefore, we conducted a retrospective study to identify the prevalence of seizures and epilepsy and risk factors of developing epilepsy in children with ischemic stroke.

\section{MATERIAL and METHODS}

This is a retrospective study about patients who had ischemic strokes at Çukurova University hospital between January 2004 and January 2014. Transient ischemic attack, hypoxic-ischemic encephalopathy, and neonatal stroke were not included in this study. The patients were divided into three subgroups: as patients with early-onset seizures, patients with late remote seizures, and patients without seizures. We classified seizures according to the International League Against Epilepsy (ILAE) criteria ${ }^{(10)}$. According to the guidelines of ILAE, early poststroke seizures were defined as those occurring within 7 days and late post-stroke seizures as unprovoked seizures developing beyond 1 week after stroke ${ }^{(3)}$.

Strokes were related to various etiologies as cardiovascular, infection, hematological disease (sickle cell anemia, and thalassemia major), prothrombotic state, trauma, nephrotic syndrome, and idiopatic.

We reviewed the medical records of our study population, retrospectively. Clinical and laboratory data such as age, gender, age at stroke, etiology, neurologic deficits, history of seizures, seizure type, seizure onset time, number of antiepileptic drugs (AEDs), epilepsy, neuroimaging findings, infarct areas (cortical, subcortical, cortico-subcortical), number of infarct areas, affected hemisphere (right, left, or bilateral), duration of follow-up, and EEG findings (focal and generalized abnormalities) were recorded.

The SPSS version 19.0 was used for statistical analysis. The chi-square tests were used to determine the associations between categorical data. We carried out univariate and multivariate analyses of potential predictors of recurrence risk using Cox regression analysis. The level of statistical significance was established at p- value of $<0.05$. Initially, we performed a univariate analysis, in order to determine which predictor would be used in multivariate analysis.

\section{RESULTS}

One hundred and two children were identified as having ischemic stroke. The mean age at stroke was $67.32 \pm 25.48$ months (1-180 months). Of the 102 patients, $56(54.9 \%)$ were boys and $46(45.1 \%)$ were girls. The median follow-up period was almost 2 years.

Of the 102 patients, 39 (38.2\%) had seizures, and $63(61.8 \%)$ had no seizures. While $27(69.2 \%)$ patients had early-onset, and 12 (30.8\%) late-onset post-

Table 1. Summary of demographics data of patients with ischemic stroke.

\begin{tabular}{|c|c|c|c|}
\hline \multicolumn{2}{|l|}{ Parameters } & \multirow{2}{*}{$\frac{\mathbf{n}}{56}$} & \multirow{2}{*}{$\frac{\%}{54.9}$} \\
\hline Gender & Boy & & \\
\hline & Girl & 46 & 45.1 \\
\hline \multirow[t]{3}{*}{ Age at stroke } & $<5$ years & 37 & 36.3 \\
\hline & $5-10$ years & 60 & 58.5 \\
\hline & $>10$ years & 5 & 4.9 \\
\hline \multirow[t]{2}{*}{ Neurologic deficits } & Yes & 75 & 73.5 \\
\hline & No & 27 & 26.5 \\
\hline \multirow[t]{2}{*}{ History of seizures } & Yes & 39 & 38.2 \\
\hline & No & 63 & 61.8 \\
\hline \multirow[t]{2}{*}{ Seizure onset time } & Early onset & 26 & 69.6 \\
\hline & Late onset & 13 & 30.4 \\
\hline \multirow[t]{2}{*}{ Type of seizure } & Partial & 26 & 60.9 \\
\hline & Generalized & 13 & 30.4 \\
\hline \multirow[t]{2}{*}{ Development of epilepsy } & Yes & 17 & 16.7 \\
\hline & No & 85 & 83.3 \\
\hline \multirow[t]{2}{*}{ Neurologic deficits } & Yes & 75 & 73.5 \\
\hline & No & 27 & 26.5 \\
\hline \multirow[t]{3}{*}{ Type of neurologic deficits } & Right hemiparesis & 32 & 42.6 \\
\hline & Left hemiparesis & 38 & 50.6 \\
\hline & Bilateral involvement & 5 & 6.8 \\
\hline \multirow[t]{3}{*}{ Lesion location } & Cortical & 50 & 49.0 \\
\hline & Noncortical & 38 & 37.3 \\
\hline & Both & 14 & 13.7 \\
\hline \multirow{4}{*}{$\begin{array}{l}\text { Number of infarct areas } \\
\text { disorders } \\
\text { Affected hemisphere }\end{array}$} & 1 & 85 & 83.3 \\
\hline & $\geq 2$ & 17 & 16.7 \\
\hline & Unilateral hemisphere & 96 & 94.1 \\
\hline & Bilateral hemisphere & 6 & 5.9 \\
\hline \multirow[t]{2}{*}{ EEG findings } & Focal abnormalities & 27 & 69.2 \\
\hline & Generalized abnormalities & 12 & 30.8 \\
\hline \multirow[t]{7}{*}{ Etiology } & Cardiac disease & 30 & 29.4 \\
\hline & Infection & 18 & 17.6 \\
\hline & Hemotological disease & 16 & 15.7 \\
\hline & Prothrombotic state & 14 & 13.7 \\
\hline & Trauma & 6 & 5.9 \\
\hline & Nephrotic syndrome & 3 & 2.9 \\
\hline & Idiopatic & 15 & 14.7 \\
\hline
\end{tabular}

EMG: Electromyelography 
Table 2. Risk factors associated with epilepsy development.

\begin{tabular}{|c|c|c|c|c|c|c|}
\hline \multirow[b]{2}{*}{ Parameters } & & \multicolumn{2}{|c|}{ Epilepsy } & \multicolumn{2}{|c|}{ No epilepsy } & \multirow[b]{2}{*}{$P$ value } \\
\hline & & $\mathbf{n}$ & $\%$ & $\mathbf{n}$ & $\%$ & \\
\hline \multirow[t]{2}{*}{ Gender } & Boy & 6 & 33.3 & 12 & 66.7 & 0.192 \\
\hline & Girl & 11 & 52.4 & 10 & 47.6 & \\
\hline \multirow[t]{3}{*}{ Age at stroke } & $<5$ years & 7 & 41.2 & 10 & 58.8 & 0.956 \\
\hline & $5-10$ years & 9 & 45 & 11 & 55 & \\
\hline & $>10$ years & 1 & 50 & 1 & 50 & \\
\hline \multirow[t]{2}{*}{ Seizure onset time } & Early onset & 7 & 26.9 & 19 & 73.1 & 0.004 \\
\hline & Late onset & 10 & 76.9 & 3 & 23.1 & \\
\hline \multirow[t]{2}{*}{ Type of seizure } & Partial & 13 & 50 & 13 & 50 & 0.213 \\
\hline & Generalized & 4 & 30.8 & 8 & 69.2 & \\
\hline \multirow[t]{2}{*}{ Neurologic deficits } & Yes & 15 & 40.5 & 22 & 59.5 & \\
\hline & No & 2 & 100 & 0 & 0 & \\
\hline \multirow[t]{3}{*}{ Type of neurologic deficits } & Right hemiparesis & 5 & 38.5 & 8 & 61.5 & 0.634 \\
\hline & Left hemiparesis & 10 & 45.5 & 12 & 54.5 & \\
\hline & Bilateral involvement & 2 & 50 & 2 & 50 & \\
\hline \multirow[t]{3}{*}{ Lesion location } & Cortical & 13 & 56.5 & 10 & 43.5 & 0.040 \\
\hline & Noncortical & 2 & 15.4 & 11 & 84.6 & \\
\hline & Both & 2 & 66.7 & 1 & 33.3 & \\
\hline \multirow[t]{2}{*}{ Number of infarct areas } & 1 & 11 & 37.9 & 18 & 62.1 & 0.199 \\
\hline & $\geq 2$ & 6 & 60 & 4 & 40 & \\
\hline \multirow[t]{2}{*}{ Affected hemisphere } & Unilateral hemisphere & 16 & 45.7 & 19 & 54.3 & 0.407 \\
\hline & Bilateral hemisphere & 1 & 25 & 3 & 75 & \\
\hline \multirow[t]{2}{*}{ EEG findings } & Focal abnormalities & 13 & 48.1 & 14 & 51.9 & 0.307 \\
\hline & Generalized abnormalities & 4 & 33.3 & 8 & 66.7 & \\
\hline
\end{tabular}

stroke seizures. Focal and generalized seizures were identified in $26(66.7 \%)$ and 13 patients (33.3\%), respectively. Epilepsy was detected in 17 (16.7\%) patients. Eight of them had early-onset and nine lateonset post-stroke seizures. Most of them (76\%) used AED as monotherapy.

Focal neurological signs were the most common presentations, but these were not risk factors for the development of epilepsy. The most common risk factors for stroke were the presence of congenital/acquired heart disease $(29.4 \%)$, central nervous system infection (17.6\%), and hematological disease (SCD, and thalassemia major) (15.7\%). In $14.7 \%(n=15)$ of children there were no identifiable risk factors.

EEG recordings were performed in all the patients who had seizures. Twenty five patients had focal, and $14(35.9 \%)$ had generalized EEG abnormalities. The demographic details of these patients are summarized in Table 1.

There was no correlation between epilepsy and gender, age at stroke, etiology, neurologic deficits, seizure type, number of foci of infarction, affected hemisphere, and EEG findings (focal and generalized abnormalities). But, a statistically significant correlation between epilepsy and lesion location, and seizure onset time was detected (Table 2). In the multivariate analysis, seizure onset time was the only risk factor for epilepsy.

\section{DISCUSSION}

Cerebrovascular disease is the most common and well-known etiology of epileptic seizures in adults. The estimated incidence of seizures after stroke in adults ranges from $0.4 \%$ to $43 \%$, with variation on the basis of stroke subtype ${ }^{(6,11)}$. Seizure is a consequence of stroke more often in children than in adults; it has been reported that the incidence rate of seizures within 24 hours of a stroke is 18 times higher in children than in adults ${ }^{(6)}$. In literature, there have been a few studies concerning the incidence on the post-stroke seizures and subsequent epilepsy, and risk factors for post-stroke epilepsy ${ }^{(7-9)}$.

We found seizures in $38.2 \%$ of the patients who 
had suffered strokes. Kopyta et al. ${ }^{(12)}$ described strokes in $26 \%$ of their 78 patients. In other studies, Incecik et al. ${ }^{(5)}$ and Morais et al. ${ }^{(13)}$ reported seizures in $35 \%$ and $64.6 \%$ of children, respectively. In our study, post-stroke epilepsy developed in only $16.7 \%$ of the patients. Similarly, Kopyta et al. ${ }^{(12)}$ reported post-stroke epilepsy rate as $13 \%$. In contrast, the incidence of epilepsy after stroke was higher in the other group of pediatric studies. Lee et al. ${ }^{(3)}$ observed seizures in $41.4 \%$, and epilepsy in $22.3 \%$ of children with stroke. Morais et al. ${ }^{(5)}$ reported that $29.2 \%$ of their patients developed post-stroke epilepsy. These discrepancies in the frequency of post-stroke epilepsy exist because different groups of children, and different populations have been investigated in each study.

We detected that the only risk factors for developing epilepsy were seizure onset time and lesion location in neuroimaging.

Lee et al. ${ }^{(3)}$ reported that epilepsy was the most common sequelae in both the early post-stroke seizure $(38.1 \%)$ and late post-stroke seizure group (100\%). Morais et al. ${ }^{(5)}$ and Yang et al. ${ }^{(14)}$ found a significant association between late post-stroke seizures and epilepsy in children after ischemic stroke similar to our study. These studies agree that late post-stroke seizure was a risk factor for post-stroke epilepsy. The occurrence of early and late post-stroke seizures parallels that of post-traumatic epilepsy. These similar pathophysiologic mechanisms are cellular biochemical dysfunction for early post-stroke seizures and epileptogenic gliotic scarring for late post-stroke seizures ${ }^{(15)}$. This high risk of post-stroke epilepsy has been also observed in the cases with late post-stroke seizures investigated in other studies ${ }^{(3,5,14)}$ and furthermore this risk is higher than that reported for the general population experiencing their first unprovoked seizures ${ }^{(16)}$. Therefore, Dhanuka et al. ${ }^{(17)}$ also made a conclusion that early post-stroke seizures were rather common, did not recur and could not be treated with AEDs. Late post-stroke seizures were less common but they were associated with poststroke epilepsy.

About seizure types, Horner et al. ${ }^{(18)}$ described that early post-stroke seizures were more likely to be generalized. On the contrary, Gupta et al. ${ }^{(19)}$ reported that early post-stroke seizures were more likely to be partial $(57 \%)$, whereas late post-stroke seizures were more likely to be generalized $(65 \%)$. We detected same finding as Gupta et al. ${ }^{(19)}$ But, there was not significant difference between focal seizures and generalized seizures and epilepsy in our study.

Previous studies reported epilepsy to be caused more often by cortical rather than noncortical involvement ${ }^{(5,20,21)}$. However, Kotila and Waltimo (22) reported that lesion location did not play any role in the development of epilepsy. Cortical involvement was also found as a risk factor for the development of epilepsy in our study.

Some studies have shown that focal cortical dysfunction on EEG was a risk for developing epilepsy ${ }^{(3)}$. But other studies have found no significant relation ${ }^{(5,7,9)}$. We also found no association between EEG findings and development of epilepsy.

In conclusion, seizures and epilepsy may occur in children with ischemic stroke. We found that cortical involvement and late onset post-stroke seizure are predictors of the development of post-stroke epilepsy. Further studies are required to identify risk factors for the development of post-stroke epilepsy in childhood ischemic stroke.

\section{REFERENCES}

1. Giroud M, Lemesle M, Gouyon JB, Nivelon JL, Milan C, Dumas R. Cerebrovascular disease in children under 16 years of age in the city of Dijon, France: a study of incidence and clinical features from 1985 to 1993. J Clin Epidemiol 1995;48:1343-1348. https://doi.org/10.1016/0895-4356(95)00039-9

2. Lynch JK, Hirtz DG, DeVeber G, Nelson KB. Report of the National Institute of Neurological Disorders and Stroke Workshop on perinatal and childhood stroke. Pediatrics 2002; 109:116-123.

https://doi.org/10.1542/peds.109.1.116

3. Lee JC, Lin KL, Wang HS, Chou ML, Hung PC, Hsieh MY, et al. Seizures in childhood ischemic stroke in Taiwan. Brain Dev 2009;31:294-299. https://doi.org/10.1016/j.braindev.2008.05.006

4. Chong B, Wong V. Pediatric stroke among Hong Kong Chinese subjects. Pediatrics 2004;114:e206-e212. https://doi.org/10.1542/peds.114.2.e206

5. Morais NM, Ranzan J, Riesgo RS. Predictors of epilepsy in children with cerebrovascular disease. J Child Neurol 2013;28:1387-1391. https://doi.org/10.1177/0883073812464270

6. Berges S, Moulin T, Berger E, Tatu L, Sablot D, Challier B, 
Rumbach L. Seizures and epilepsy following strokes: recurrence factors. Eur Neurol 2000;43:3-8. https://doi.org/10.1159/000008120

7. Singh RK, Zecavati N, Singh J, Kaulas H, Nelson KB, Dean NP, et al. Seizures in acute childhood stroke. J Pediatr 2012;160:291-296. https://doi.org/10.1016/j.jpeds.2011.07.048

8. De Reuck J, Goethals M, Vonck K, Van Maele G. Clinical predictors of late-onset seizures and epilepsy in patients with cerebrovascular disease. Eur Neurol 2005;54:68-72. https://doi.org/10.1159/000087715

9. Chedehumbe MA, Khatri P, Khoury JC, Alwell K, Szaflarski JP, Broderick JP, et al. Seizures are common in the acute set of childhood stroke: a populationbased study. J Child Neurol 2009;24:9-12. https://doi.org/10.1177/0883073808320756

10. Proposal for revised clinical and electroencephalographic classification of epileptic seizures. From the Commission on Classification and Terminology of the International League Against Epilepsy. Epilepsia 1981;22:489-501. https://doi.org/10.1111/j.1528-1157.1981.tb06159.x

11. Burn J, Dennis M, Bamford J, Sandercock P, Wade D, Warlow C. Epileptic seizures after a first stroke: the Oxfordshire community stroke Project. BMJ 1997;315:15821587. https://doi.org/10.1136/bmj.315.7122.1582

12. Kopyta I, Sarecka-Hujar B, Skrzypek M. Post-stroke epilepsy in Polish paediatric patients. Dev Med Child Neurol 2015;57:821-828. https://doi.org/10.1111/dmen.12711

13. Incecik F, Ozlem Hergüner M, Altunbasak S. Risk factors and treatment outcomes for children with arterial ischemic stroke. J Clin Neurosci 2010;17:1000-1002. https://doi.org/10.1016/j.jocn.2010.01.004

14. Yang JS, Park YD, Hartlage PL. Seizures associated with stroke in childhood. Pediatr Neurol 1995;12:136-138. https://doi.org/10.1016/0887-8994(94)00152-R

15. Silverman IE, Restrepo L, Mathews GC. Poststroke seizures. Arch Neurol 2002;59:195-201. https://doi.org/10.1001/archneur.59.2.195

16. Hauser WA, Rich SS, Lee JR, Annegers JF, Anderson VE. Risk of recurrent seizures after two unprovoked seizures. $N$ Engl J Med 1998;338:429-434. https://doi.org/10.1056/NEJM199802123380704

17. Dhanuka AK, Misra UK, Kalita J. Seizures after stroke: a prospective clinical study. Neurol India 2001;49:33-36.

18. Horner S, Ni XS, Duft M, Niederkorn K, Lechner H. EEG, $\mathrm{CT}$ and neurosonographic findings in patients with postischemic seizures. J Neurol Sci 1995;132:57-60. https://doi.org/10.1016/0022-510X(95)00122-I

19. Gupta SR, Naheedy MH, Elias D, Rubino FA. Postinfarction seizures. A clinical study. Stroke 1988;19:1477-1481. https://doi.org/10.1161/01.STR.19.12.1477

20. Arboix A, Garcia-Eroles L, Massons JB, Oliveres M, Comes E. Predictive factors of early seizures after acute cerebrovascular disease. Stroke 1997;28:1590-1594. https://doi.org/10.1161/01.STR.28.8.1590

21. Bladin CF, Alexandrov AV, Bellavance A, Bornstein N, Chambers B, Coté R, et al. Seizures after stroke: a prospective multicenter study. Arch Neurol 2000;57:1617-1622. https://doi.org/10.1001/archneur.57.11.1617

22. Kotila M, Waltimo O. Epilepsy after stroke. Epilepsia 1992;33:495-498 https://doi.org/10.1111/j.1528-1157.1992.tb01698.x 